\title{
Use of Sunflower Cake in the Diet of ISA Brown Pullets
}

\author{
Anastasios Kargopoulos ${ }^{1}$, Eleftherios Bonos ${ }^{2}$, Zoitsa Basdagianni ${ }^{3}$ and Ioannis Nikolakakis ${ }^{1}$ \\ 1. Department of Agricultural Technology, Division of Animal Production, Technological Educational Institution of Western \\ Macedonia, Florina 53100, Greece
}

2. Research Institute of Animal Science/Hellenic Agricultural Organization-Dimiter, Paralimni Giannitsa, Pella 58100, Greece

3. Faculty of Agriculture, Forestry and Natural Environment, School of Agriculture, Aristotle University of Thessaloniki, Thessaloniki 54124, Greece

\begin{abstract}
Recently, feed ingredient prices and availability concerns have resulted in the examination of diet formulations using alternative, locally available, high protein feed ingredients. An experiment was carried out to evaluate sunflower cake (SC) dietary effect on the performance of ISA brown pullets. The duration of the experiment was 20 weeks. A total of 48 one-day-old pullets were randomly allocated in three groups $\left(\mathrm{C}, \mathrm{SC}_{6.25}\right.$ and $\left.\mathrm{SC}_{12.5}\right)$ with four replications. The pullets of the control group (C) were given proper full rations without sunflower cake for the 1st, 2 nd and 3rd rearing ages, whereas in the treatment groups $\mathrm{SC}_{6.25}$ sunflower cake was added at $6.25 \%$ of rations and in group $\mathrm{SC}_{12.5}$ at $12.5 \%$ of rations. The pullets were housed in floor pens with litter and were offered feed and water ad libitum. According to the results of statistical analysis, the addition of $6.25 \%$ sunflower cake in the diet significantly $(P<0.05)$ affected body weight gain and feed conversion ratio. The results of this study showed that sunflower cake can be added to the ration of ISA brown pullets of 0-20 weeks of age up to $12.5 \%$ without any adverse effect on their performance.
\end{abstract}

Key words: ISA brown pullets, sunflower seed cake, feed ingredients, performance.

\section{Introduction}

The increasing feed ingredient prices remain the greatest single parameter that determines profit margins in poultry production. Corn and soybean meal have been used as basal feed ingredients in poultry feed formulation for decades, but recently their high prices have resulted in examining of diet formulations using alternative, locally available, high protein ingredients, thereby decreasing feed costs $[1,2]$. Although the use of such ingredients in poultry rations may be beneficial from a cost standpoint, it could have detrimental effects to poultry performance, because fiber in poultry is considered as something that "dilutes" the composition of other feed ingredients, such as energy and crude protein [3], which can have adverse effects on feed consumption and digestibility of feed components [4]. On the other hand, increased dietary fiber can have positive effects, such as better

Corresponding author: Ioannis Nikolakakis, Ph.D., research fields: animal nutrition and physiology of nutrition. satiety, improved behaviour and better overall welfare [2].

Sunflower cake or sunflower meal is an important by-product of the oil extraction from the sunflower seed $[5,6]$. Sunflower cake is a good feed ingredient for livestock, containing high amounts of protein (22\%-44\%) with good amino acid composition and average amounts of energy $[5,7,8]$. The fiber content of sunflower cake can vary within 12\%-32\%, depending on the degree of hull removal and the method used for the oil extraction. Another important characteristic is that sunflower cake does not contain anti-nutritional factor, in contrast with other common feed ingredients (soybean meal, cottonseed meal, rapeseed meal) [6]. Sunflower cake is usually cheaper than soybean meal and can be produced in countries that do not produce soybeans $[5,6]$. In recent years, the dietary use of sunflower cake is under examination in ruminants, pigs and poultry [5, 9-11].

Therefore, the aim of this work was to study the possibility of using sunflower cake as an alternative to 
imported soybean meal in the diets of ISA brown pullets.

\section{Materials and Methods}

\subsection{Sunflower Cake}

Ground sunflower cake (screen diameter $<2.0 \mathrm{~mm}$ ) mixture, a product of New Energy SA (Greece), from cultivated hybrids Dalia CS, Imeria CS, Robia CS, Fabiola CS, Klarika CL, Fushia CL, Codicap, Neomia NK, Sanay MR and Tristan, were used in this study. Table 1 presents the chemical composition of the examined sunflower cake.

\subsection{Experimental Rations, Pullets, Housing and} Design

For the purposes of the experiment, a total of 48 one-day-old ISA brown pullets were used. The pullets were randomly allocated in three groups $\left(\mathrm{C}, \mathrm{SC}_{6.25}\right.$ and $\mathrm{SC}_{12.5}$ ) with four replications (cage) of four pullets per cage. Hence, the complete experimental setup was three experimental treatments $\times$ four replicates $\times$ four pullets. Each replication was housed in a floor cage with wheat straw litter, equipped with a semiautomatic feeder and a semi-automatic drinker. Before the transfer of pullets in the experimental cages, the building was preheated for $12 \mathrm{~h}$, so that the temperature on arrival of the birds was $30{ }^{\circ} \mathrm{C}$. During the first $7 \mathrm{~d}, 22-23 \mathrm{~h}$ of light with intensity 30 lux was provided to encourage intake of water and food and afterwards a normal decreasing lighting program was applied. Especially, hours of light with 15 lux during the $2 \mathrm{nd}, 3 \mathrm{rd}$, 4th, 5th and 6th week were 18, 16, 15, 13 and $12 \mathrm{~h}$, respectively, and for the rest weeks of experiment $11 \mathrm{~h}$ stably. Drinkers were cleaned daily at the first three weeks and then once a week throughout all the period of the experiment. Starter diet was distributed 4-5 $\mathrm{h}$ after delivery of pullets. Stocking density was about $0.5 \mathrm{~m}^{2}$ per pullet. The initial temperature for the first three weeks was $30^{\circ} \mathrm{C}$ at the edge of each brooder $\left(26^{\circ} \mathrm{C}\right.$ at $1.5 \mathrm{~m}$ from the brooder) and afterwards the temperature was gradually decreased [12]. Relative humidity throughout of experiment ranged from $55 \%$ to $60 \%$.

Pullets of the control group (C) consumed proper full rations without sunflower cake for the 1st, 2nd and 3rd ages based on corn and soybean meal, whereas in treatment groups $\mathrm{SC}_{6.25}$, sunflower cake was added at $6.25 \%$ of rations and $12.5 \%$ for group $\mathrm{SC}_{12.5}$ replacing soybean meal. The three diets for each age (0-6 weeks, 7-14 weeks and 15-20 weeks) of

Table 1 Chemical composition of sunflower cake.

\begin{tabular}{ll}
\hline Composition & Content $(\mathrm{g} / \mathrm{kg})$ \\
\hline Chemical analysis & \\
\hline Dry matter & 944.0 \\
Crude protein & 258.0 \\
Ether extract & 22.0 \\
Crude fiber & 238.8 \\
Ash & 61.9 \\
\hline Calculated analysis* & \\
\hline Lysine & 10.0 \\
Methionine & 5.0 \\
Methionine + cystine & 10.0 \\
Threonine & 10.5 \\
Ca & 2.1 \\
P available & 1.4 \\
ME $(\mathrm{kcal} / \mathrm{kg}) * *$ & $1,711.0$ \\
$*$ Estimations were based on National Research Council $(\mathrm{NRC})[13]$. \\
$* *$ ME: metabolizable energy, it was calculated according to NRC [13]: ME $=(36.63 \times$ crude protein $)+(77.97 \times$ ether extract $)+$ \\
$(19.87 \times$ nitrogen-free extract).
\end{tabular}


Table 2 Ingredients and chemical analysis of experimental pullet rations.

\begin{tabular}{|c|c|c|c|c|c|c|c|c|c|}
\hline \multirow{3}{*}{ Ingredients (g/kg) } & \multicolumn{9}{|c|}{ Treatments } \\
\hline & \multicolumn{3}{|c|}{ 1st age (0-6 weeks) } & \multicolumn{3}{|c|}{ 2nd age (7-14 weeks) } & \multicolumn{3}{|c|}{ 3rd age (15-20 weeks) } \\
\hline & $\mathrm{C}$ & $\mathrm{SC}_{6.25}$ & $\mathrm{SC}_{12.5}$ & $\mathrm{C}$ & $\mathrm{SC}_{6.25}$ & $\mathrm{SC}_{12.5}$ & $\mathrm{C}$ & $\mathrm{SC}_{6.25}$ & $\mathrm{SC}_{12.5}$ \\
\hline Corn seed & 503.0 & 454.0 & 406.3 & 598.0 & 550.4 & 503.4 & 500.4 & 590.5 & 595.1 \\
\hline Barley & 50.0 & 50.0 & 50.0 & 50.0 & 50.0 & 50.0 & 227.1 & 98.5 & 50.0 \\
\hline Soybean meal 44\% & 313.0 & 280.2 & 253.4 & 249.3 & 219.0 & 188.4 & 196.5 & 172.5 & 144.3 \\
\hline Herring $72 \%$ & 20.0 & 20.0 & 20.0 & 20.0 & 20.0 & 20.0 & - & - & - \\
\hline Wheat bran & 20.0 & 20.0 & 20.0 & 20.0 & 20.0 & 20.0 & 20.0 & 20.0 & 20.0 \\
\hline Sunflower cake & - & 62.5 & 125.0 & - & 62.5 & 125.0 & - & 62.5 & 125.0 \\
\hline Sunflower oil & 38.0 & 50.0 & 50.0 & 6.7 & 22.1 & 37.2 & - & - & 9.6 \\
\hline Vegetable fat & - & 3.8 & 19.3 & - & - & - & - & - & - \\
\hline $\mathrm{CaCO}_{3}$ & 16.00 & 16.00 & 16.00 & 16.00 & 16.00 & 16.00 & 16.00 & 16.00 & 16.00 \\
\hline $\begin{array}{l}\text { Monocalcium phosphate } \\
\text { (MCP) }\end{array}$ & 12.50 & 12.50 & 12.50 & 12.50 & 12.50 & 12.50 & 12.50 & 12.50 & 12.50 \\
\hline Sodium carbonate & 3.00 & 3.00 & 3.00 & 3.00 & 3.00 & 3.00 & 3.00 & 3.00 & 3.00 \\
\hline Salt & 3.00 & 3.00 & 3.00 & 3.00 & 3.00 & 3.00 & 3.00 & 3.00 & 3.00 \\
\hline L-lysine $\mathrm{HCl}$ & 3.50 & 3.50 & 3.50 & 3.50 & 3.50 & 3.50 & 3.50 & 3.50 & 3.50 \\
\hline DL-methionine (99\%) & 3.00 & 3.00 & 3.00 & 3.00 & 3.00 & 3.00 & 3.00 & 3.00 & 3.00 \\
\hline Threonine & 2.00 & 2.00 & 2.00 & 2.00 & 2.00 & 2.00 & 2.00 & 2.00 & 2.00 \\
\hline Formic acid & 2.50 & 2.50 & 2.50 & 2.50 & 2.50 & 2.50 & 2.50 & 2.50 & 2.50 \\
\hline $\begin{array}{l}\text { Vitamins and trace } \\
\text { minerals premix** }\end{array}$ & 2.50 & 2.50 & 2.50 & 2.50 & 2.50 & 2.50 & 2.50 & 2.50 & 2.50 \\
\hline Probiotic & 2.00 & 2.00 & 2.00 & 2.00 & 2.00 & 2.00 & 2.00 & 2.00 & 2.00 \\
\hline Xylanase & 2.00 & 2.00 & 2.00 & 2.00 & 2.00 & 2.00 & 2.00 & 2.00 & 2.00 \\
\hline Phytase & 2.00 & 2.00 & 2.00 & 2.00 & 2.00 & 2.00 & 2.00 & 2.00 & 2.00 \\
\hline Coccidiostatic & 2.00 & 2.00 & 2.00 & 2.00 & 2.00 & 2.00 & 2.00 & 2.00 & 2.00 \\
\hline Total & $1,000.00$ & $1,000.00$ & $1,000.00$ & $1,000.00$ & $1,000.00$ & 1000.00 & $1,000.00$ & $1,000.00$ & $1,000.00$ \\
\hline \multicolumn{10}{|l|}{ Chemical analysis (g/kg) } \\
\hline Dry matter & 864.0 & 852.4 & 844.5 & 891.0 & 880.7 & 870.6 & 896.2 & 899.5 & 894.5 \\
\hline Crude protein & 200.0 & 200.0 & 200.0 & 180.0 & 180.0 & 180.0 & 160.0 & 160.0 & 160.0 \\
\hline Ether extract & 63.0 & 76.0 & 83.0 & 35.0 & 31.0 & 31.0 & 25.3 & 27.6 & 37.6 \\
\hline Crude fiber & 41.0 & 50.0 & 62.0 & 36.0 & 47.0 & 60.3 & 40.0 & 49.0 & 60.0 \\
\hline \multicolumn{10}{|l|}{ Calculated analysis* } \\
\hline ME (kcal/kg) & $2,940.0$ & $2,940.0$ & $2,940.0$ & 2,840 & 2,840 & 2,840 & 2,740 & 2,740 & 2,740 \\
\hline Lysine $(\mathrm{g} / \mathrm{kg})$ & 14.5 & 14.4 & 13.8 & 13.0 & 12.6 & 12.2 & 10.7 & 10.4 & 10.0 \\
\hline $\begin{array}{l}\text { Methionine }+ \text { cystine } \\
(\mathrm{g} / \mathrm{kg})\end{array}$ & 9.8 & 9.8 & 9.8 & 9.2 & 9.2 & 9.3 & 8.3 & 8.4 & 8.4 \\
\hline $\mathrm{Ca}(\mathrm{g} / \mathrm{kg})$ & 9.9 & 10.0 & 9.9 & 9.9 & 10.0 & 10.0 & 9.4 & 9.4 & 9.4 \\
\hline Available P (g/kg) & 4.5 & 4.4 & 4.4 & 4.4 & 4.3 & 4.3 & 4.4 & 4.1 & 4.0 \\
\hline
\end{tabular}

* Calculated analysis based on NRC tables [1].

** Composition of vitamins and trace minerals premix per kg of diet: 12,000 IU vitamin A; 5,000 IU vitamin $\mathrm{D}_{3} ; 100 \mathrm{mg}$ vitamin $\mathrm{E}$; $4 \mathrm{mg}$ vitamin $\mathrm{K}_{3} ; 2.60 \mathrm{mg}$ vitamin $\mathrm{B}_{1} ; 8 \mathrm{mg}$ vitamin $\mathrm{B}_{2} ; 3 \mathrm{mg}$ vitamin $\mathrm{B}_{6} ; 0.015 \mathrm{mg}$ vitamin $\mathrm{B}_{12} ; 10 \mathrm{mg}$ vitamin $\mathrm{C} ; 85 \mathrm{mg}$ niacin; 2 $\mathrm{mg}$ folic acid; $20 \mathrm{mg}$ panthothenic acid; $0.20 \mathrm{mg}$ biotin; $500 \mathrm{mg}$ choline chloride; $120 \mathrm{mg} \mathrm{Mn} ; 100 \mathrm{mg} \mathrm{Zn;} 40 \mathrm{mg} \mathrm{Fe;} 20 \mathrm{mg} \mathrm{Cu} ; 1$ mg I; $0.30 \mathrm{mg} \mathrm{Se}$; $0.20 \mathrm{mg}$ Co.

the pullets were isonitrogenous and isonitrogenous (Table 2) and appropriate for the birds rearing stage $[12,13]$. The consumption of water and food were ad libitum.

\subsection{Experimental Measurements}

During the experiment, samples were taken of the experimental diets and sunflower cake, which were analysed according to the Weende methods [14]. In particular, the identification of crude protein $(\mathrm{CP})$ was performed using the Kjeldahl method in semiautomatic equipment Buchi; ether extracts (EE) with a Soxhlet extractor with ether petroleum; crude fiber (CF) using a fibrous automatic Fibertech Tecator 
device; the dry matter measuring weight loss after placing the sample in an oven to constant weight. Nitrogen free extract (NFE) was calculated as Eq. (1):

$$
\begin{aligned}
\mathrm{NFE}= & \text { dry matter } \%-(\mathrm{CP} \%+\mathrm{EE} \% \\
& +\mathrm{CF} \%+\mathrm{ash} \%)
\end{aligned}
$$

Metabolizable energy $(\mathrm{kcal} / \mathrm{kg})$ was calculated according to National Research Council (NRC) [13], as Eq. (2):

$$
\mathrm{ME}=36.63 \times \mathrm{CP}+77.97 \times \mathrm{EE}+19.87 \times \mathrm{NFE}(2)
$$

At every day of the experiment, the feed intake was determined by measuring leftover feed, and at every week the bodyweight of each pullet was individually measured. Feed efficiency was calculated as Eq. (3):

Feed efficiency $=$

weight gain of pullet during the same period

$$
\text { feed supplied to pullet }
$$

\subsection{Statistical Analysis}

In this trial, the replication (cage) was considered as the experimental unit. The statistical processing of the experimental data was performed using the least squares analysis of variance [15]. The differences of averages were evaluated using Duncan's test. Significant differences among treatment means were tested at the 0.05 probability level. The statistical analysis was made with the help of the SPSS statistical software package [16].

\section{Results}

Table 3 presents the effect of sunflower cake supplementation on the performance parameters of the pullets. Feed intake was significantly $(P<0.05)$ higher in the control group during the first rearing period (0-6 weeks) compared to the other two groups. But this effect was reversed during the other two rearing periods (7-14 weeks and 15-20 weeks), where the pullets of the control group consumed less feed than the pullets of the other two groups. Growth rate did not differ during the first age period among the group, but was significantly $(P<0.05)$ better for the $\mathrm{SC}_{6.25}$ group, compared to the control group during the second and third age of the pullets, as well as overall. In addition, feed efficiency was not different during the first and second age, but was significantly $(P<$ 0.05 ) better for the $\mathrm{SC}_{6.25}$ group during the third

\begin{tabular}{|c|c|c|c|c|c|}
\hline \multirow{2}{*}{ Performance } & \multicolumn{3}{|c|}{ Treatments } & \multirow{2}{*}{ SE } & \multirow{2}{*}{$P$} \\
\hline & $\mathrm{C}$ & $\mathrm{SC}_{6.25}$ & $\mathrm{SC}_{12.5}$ & & \\
\hline \multicolumn{6}{|l|}{ Feed intake (g/day) } \\
\hline 1st age (0-6 weeks) & $28.0^{\mathrm{a}}$ & $26.0^{\mathrm{b}}$ & $26.0^{\mathrm{b}}$ & 0.4 & $*$ \\
\hline 2nd age (7-14 weeks) & $62.0^{\mathrm{a}}$ & $63.8^{\mathrm{b}}$ & $63.0^{\mathrm{b}}$ & 0.5 & $*$ \\
\hline 3rd age (15-20 weeks) & $81.8^{\mathrm{a}}$ & $83.0^{\mathrm{b}}$ & $84.2^{\mathrm{b}}$ & 0.7 & $*$ \\
\hline Average & 56.1 & 56.4 & 56.4 & 0.3 & NS \\
\hline \multicolumn{6}{|c|}{ Body weight gain (g/day) } \\
\hline 1st age (0-6 weeks) & 10.7 & 10.9 & 10.8 & 0.2 & NS \\
\hline 2nd age (7-14 weeks) & $13.1^{\mathrm{a}}$ & $14.4^{\mathrm{b}}$ & $13.8^{\mathrm{ab}}$ & 0.3 & $*$ \\
\hline 3rd age (15-20 weeks) & $10.2^{\mathrm{a}}$ & $12.1^{\mathrm{b}}$ & $10.8^{\mathrm{a}}$ & 0.3 & $*$ \\
\hline Average & $11.4^{\mathrm{a}}$ & $12.5^{\mathrm{b}}$ & $11.8^{\mathrm{ab}}$ & 0.4 & $*$ \\
\hline \multicolumn{6}{|c|}{ Feed efficiency ( $\mathrm{g}$ of weight gain/g of feed) } \\
\hline 1st age (0-6 weeks) & 2.6 & 2.4 & 2.4 & 0.1 & NS \\
\hline 2nd age (7-14 weeks) & 4.7 & 4.4 & 4.6 & 0.2 & NS \\
\hline 3rd age (15-20 weeks) & $8.1^{\mathrm{a}}$ & $6.9^{\mathrm{b}}$ & $7.8^{\mathrm{a}}$ & 0.3 & $*$ \\
\hline Average & $4.9^{\mathrm{a}}$ & $4.5^{\mathrm{b}}$ & $4.8^{\mathrm{a}}$ & 0.2 & $*$ \\
\hline
\end{tabular}
rearing age, and overall, compared to the control group, but also the $\mathrm{SC}_{12.5}$ group.

Table 3 Effect of sunflower cake on pullet performance. 
Mortality was very low, as only one pullet in the $\mathrm{SC}_{12.5}$ group died at the beginning of the second age period.

\section{Discussion}

The sunflower cake examined in this experiment is a relatively high protein feed ingredient with moderate amount of crude fiber. When it is used as a soybean meal replacement, it is expected that the overall crude fiber content of the diet will increase. In this experiment, on average, $62.5 \mathrm{~g} / \mathrm{kg}$ of sunflower cake were used to replace about $30 \mathrm{~g} / \mathrm{kg}$ of soybean meal in the diets of the second group $\left(\mathrm{SC}_{6.25}\right)$, and $125 \mathrm{~g} / \mathrm{kg}$ of sunflower cake were used to replace about $60 \mathrm{~g} / \mathrm{kg}$ of soybean meal in the diets of the third group $\left(\mathrm{SC}_{12.5}\right)$. As expected, this replacement increased crude fiber by about $10 \mathrm{~g} / \mathrm{kg}$ for the diets of the second group and 20 $\mathrm{g} / \mathrm{kg}$ for those of the third group, respectively. Diets for growing poultry are generally formulated with low fiber, often at levels less than 3\%. Nevertheless, recently these generalizations are being reevaluated, because the demand for soybean meal is increasing along with its cost, making other proteinaceous feeds with comparably higher crude fiber contents more appealing, due to their significantly lower cost [2].

The results of this study are in partial agreement with those of Kalmendal et al. [10], who observed that the growth rate of the chickens increased linearly with the increasing participation of sunflower cake in the diet, while the food utilization decreased significantly when the ration included sunflower cake at $30 \%$, but not when add a smaller percentage. It has been suggested that increased consumption of fiber increases the rate of passage of the feed through the digestive tract [2], but its effect is also influenced by feed particle size and solubility [17]. Hetland et al. [18, 19] observed beneficial effects of fiber inclusion in the diet of pullets, which may be due in improvements in nutrient digestibility, growth rate, health and animal welfare [10, 20, 21], although these effects are likely depended on the amount and type of dietary fiber, as well as on the composition of the basal diet [22]. Pottgüter [1] further observed that higher fiber content in pullet feed also helps to get used to eating a larger volume of feed, forcing the pullets to spend more time eating. Abdallah et al. [23] claimed that the improvement in growth performance may be attributed to the effect of fiber on the length of the small intestine and the weight of gizzard and ceca.

\section{Conclusions}

Although sunflower cake has a relative moderate content of crude fiber, it is a valuable protein source for pullets and could be included in their diets up to a level of $125 \mathrm{~g} / \mathrm{kg}$ without any adverse effects on their performance. Therefore, sunflower cake could potentially be a viable cheaper and eco-friendly alternative to imported soybean meal proteins in ISA brown pulled diets.

\section{References}

[1] Pottguter, R. 2008. "Fiber in Layer Diets." Lohmann Information 43 (2): 22-31.

[2] Panaite, C. V., Criste, R. D., Dragotoiu, D., Panaite, T. D., and Olteanu, M. 2016. "Effect of Crude Fiber Concentration in Pullet Diets (9-16 Weeks) on Their Subsequent Performance.” Agrolife Sci. J. 5 (1): 161-7.

[3] Rougiere, N., and Carre, B. 2010. "Comparison of Gastrointestinal Transit Times between Chickens from D+ and D- Genetic Lines Selected for Divergent Digestion Efficiency." Animal 4 (11): 1861-72.

[4] Mateos, G. G., Lzaro, R., and Gracia, M. I. 2002. "The Feasibility of Using Nutritional Modifications to Replace Drugs in Poultry Feeds." J. Appl. Poultry Res. 11: 437-52.

[5] Bonos, E., Christaki, E., and Florou-Paneri, P. 2011. "The Sunflower Oil and the Sunflower Meal in Animals Nutrition.” J. Hellenic Vet. Med. Soc. 62 (1): 58-70.

[6] Senkoylu, N., and Dale, N. 1999. "Sunflower Meal in Poultry Diets: A Review." World's Poultry Sci. J. 55 (2): 153-74.

[7] Berwanger, E., Nunes, R. V., Pasqueti, T. J., Murakami, A. E., De Oliveira, T. M., Bayerle, D. F., and Frank, R. 2017. "Sunflower Cake with or without Enzymatic Complex for Broiler Chickens Feeding.” Asian Austral. J. Anim. Sci. 30 (3): 410-6.

[8] Qwele, K., Hugo, A., Oyedemi, S. O., Moyo, B., Masika, P. J., and Muchenje, V. 2013. "Chemical Composition, 
Fatty Acid Content and Antioxidant Potential of Meat from Goats Supplemented with Moringa (Moringa oleifera) Leaves, Sunflower Cake and Grass Hay." Meat Sci. 93 (3): 455-62.

[9] Irshaid, R. H., Hard, M. Y., and Titi, H. H. 2003. "Replacing Soybean Meal with Sunflower Seed Meal in the Ration of Awassi Ewes and Lambs." Small Ruminant Res. 50 (1): 109-16.

[10] Kalmendal, R., Elwinger, K., Holm, L., and Tauson, R. 2011. "High-Fibre Sunflower Cake Affects Small Intestinal Digestion and Health in Broiler Chickens." British Poultrty Sci. 52 (1): 86-96.

[11] De Carvalho Carellos, D., De Freitas Lima, J. A., Fialho, E. T., De Freitas, R. T. F., Silva, H. O., Branco, P. A. C., De Souza, Z. A., and Neto, J. V. 2005. "Evaluation of Sunflower Meal on Growth and Carcass Traits of Finishing Pigs." Cienc. Agrotecnol. 29 (1): 208-15.

[12] ISA Brown. 2016. ISA Brown Management Guide. Peterborough, UK: Joice and Hill.

[13] National Research Council (NRC). 1994. Nutrient Requirements of Poultry, 9th ed.. Washington, USA: National Academy Press.

[14] Association of Analytical Chemist (AOAC). 2005. Official Methods of Analysis of AOAC International. Arlington, Virginia: AOAC.

[15] Steel, R. G. D., and Torrie, J. H. 1980. Principles and Procedures of Statistics: A Biometrical Approach, 2nd ed.. New York, USA: McGraw- Hill Book Co.

[16] SPSS. 2008. SPSS for Windows Version 17.0. Chicago,
USA: SPSS Inc.

[17] Lindberg, J. E. 2014. "Fiber Effects in Nutrition and Gut Health in Pigs.” J. Anim. Sci. Biotechnol. 5 (1): 15.

[18] Hetland, H., Svihus, B., and Choct, M. 2005. "Role of Insoluble Fiber on Gizzard Activity in Layers." J. Appl. Poultry Res. 14 (1): 38-46.

[19] Hetland, H., and Svihus, B. 2007. "Inclusion of Dust Bathing Materials Affects Nutrient Digestion and Gut Physiology of Layers.” J. Appl. Poultry Res. 16 (1): 22-6.

[20] Gonzalez-Alvaradao, J. M., Jimenez-Moreno, E., Gonzalez Sanchez, D., Lazaro, R., and Mateos, G. G. 2010. "Effect of Inclusion of Oat Hulls and Sugar Beet Pulp in the Diet on Productive Performance and Digestive Traits of Broilers from 1 to 42 Days of Age." Animal Feed Sci. Technol. 162 (1): 37-46.

[21] Varastegani, A., and Dahlan, I. 2014. "Influence of Dietary Fiber Levels on Feed Utilization and Growth Performance in Poultry." J. Anim. Prod. Adv. 4 (6): 422-9.

[22] Amerah, A. M., Ravindran, V., and Lentle, R. G. 2009. "Influence of Insoluble Fibre and Whole Wheat Inclusion on the Performance, Digestive Tract Development and Ileal Microbiota Profile of Broiler Chickens." British Poultry Sci. 50 (3): 366-75.

[23] Abdallah, A. G., Beshara, M. M., and Ibrahim, A. F. 2015. "Effect of Different Levels and Sources of Dietary Fiber on Productive and Economical Performance in Local Laying Hens during Growing Period and Subsequent Laying Performance." Egypt Poultry Sci. 35 (1): 367-98. 